\title{
RESOURCE POTENTIAL OF BIOETHANOL AND BIODIESEL PRODUCTION IN UKRAINE
}

\section{Grygorii Kaletnik, Olena Prutska, Natalia Pryshliak}

\author{
Vinnytsia National Agrarian University, Vinnytsia, Ukraine
}

\begin{abstract}
Recently the biofuel production has significantly increased all over the world. In Ukraine this trend is increasing under the influence of such factors as the need to overcome the energy shortage, reduce dependence on oil imports and availability of powerful natural resource potential. The aim of the article is assessment of the resource potential of bioethanol and biodiesel production in Ukraine both for domestic needs and for export. Data from the State Statistics Committee of Ukraine on production and exports volumes of major bioenergy crops is analyzed and the potential volume of biofuels production in Ukraine is calculated for achievement the research objectives. The importance of shift from exportoriented agriculture to energy crops production for their processing into biofuels within the country is described.
\end{abstract}

Keywords: biodiesel, bioethanol, Ukraine, resource potential

\section{Introduction}

The increasing cost of traditional energy sources, growing shortage of energy resources and negative environmental impact of fossil fuel consumption are the main driving forces of worldwide growth of biofuel production. The bioenergy development is particularly important in Ukraine for further economic growth in line with international standards. The production of biofuels is one of the main catalysts of new global trends in the agricultural sector of Ukraine considering the present stage of state development. It is caused by limiting deposits of natural resources, the high country dependence on oil import, the structural changes in agricultural production, the permanent growth of price disparity for energy, industrial and agricultural products.

Ukraine having considerable natural and resource potential for growing various agricultural crops should convert from export-oriented agriculture to growing of energy crops for their processing into the biofuel within the country. The urgency of Ukraine's transition to using biocrops for liquid biofuels production has led to a thorough investigation in this area by many universities and research centers of Ukraine. Thus, in Vinnytsia National Agrarian University was created Ukraine's only Department of management of alternative energy sources. Leading scientists united there to address the issue of efficient biofuel production in Ukraine in terms of food, energy and environmental security. The results of their research are highlighted in different scientific works such as "The development of the biofuels market in Ukraine" (Kaletnik, 2008), "Biofuels. Food, energy and environmental security of Ukraine" (Kaletnik, 2010), "New technologies of bioconversion" (Blum, Geletukha, Grygoryuk and Dubrovin, 2010), "Ukraine Alternative energy: features operation and Development Prospects" (Kaletnik, Oliynichuk and Skoruk, 2012) and others.

Many leading international and Ukrainian scientists devoted their scientific works to research of resource potential for biofuels production, in particular Robert C. Brown (Brown, 2003), M. Royik (Royik, Kurilo, Hanzhenko and Humentyk, 2012), S. Oliynichuk, (Ukrainets, Homichak, Shiyan and Oliynichuk, 2007), Y. Blum (Blum, Geletukha and Grygoryuk, 2010), M. Kovalko (Kovalko, 2009) and many others.

However the problem of overcoming the energy deficit in Ukraine by introducing production and consumption of biofuels requires further research. This result should be obtained by reorientation of Ukrainian agriculture from export-oriented to the production of biofuel within the country for providing state food, energy and environmental security.

\section{Material and methods}

The aim of the article is reasoning of considerable resource potential of Ukrainian economy agricultural sector for increasing bioethanol and biodiesel production in Ukraine both for domestic needs and for export without negative influence on the state environmental and food security.

We have compared supply parameters of arable lands per one resident of Ukraine, the European average and regulations to ensure the satisfaction of food requirements for achievement of the research objectives. Besides the production and export parameters analysis of main grain crops, rapeseed and soybean have been conducted; it showed the increasing trend of production export part, about $50-80 \%$. The potential volumes of bioethanol and biodiesel production from the exported raw materials have been calculated. The indices of State Statistics Committee of Ukraine, Ukrainian scientific research institute of alcohol and foods biotechnology, technological standards in fuel consumption, average values of Ukraine bioethanol and biodiesel output per unit of raw materials etc. have been used for calculations.

\section{Results and discussion}

The Ukrainian agricultural sector has a considerable potential for growing feedstock necessary for bioenergy production. Nowadays the total area of agricultural lands is $\mathbf{4 1 . 9}$ million hectares, including 32.5 million hectares of arable lands (State Statistics Service of Ukraine). There is 0.93 hectare of agricultural lands per one resident of Ukraine (the population is 45 million people), including 0.72 hectares of arable lands. The average European parameters are 0.44 and 0.25 hectares.

The guarantee of state food security becomes the most important problem if the part of agricultural raw materials is used for the production of biofuels. The conducted calculations show that Ukraine has a considerable potential for the growing of biomass suitable for usage without any threat of state food security because Ukrainian agricultural production both covers the internal demand and is considerably exported. According to State Statistics Service of Ukraine it is necessary to have $0.5-0.6$ hectares of agricultural land per one person for growing crops (State Statistics Service of Ukraine) to satisfy the food needs. That's why the total area of agricultural land is 25.28 million hectares (multiplying by a factor of 0.778 we will get 20 million hectares of arable land). The total area of arable lands in Ukraine is 32.5 million hectares. 


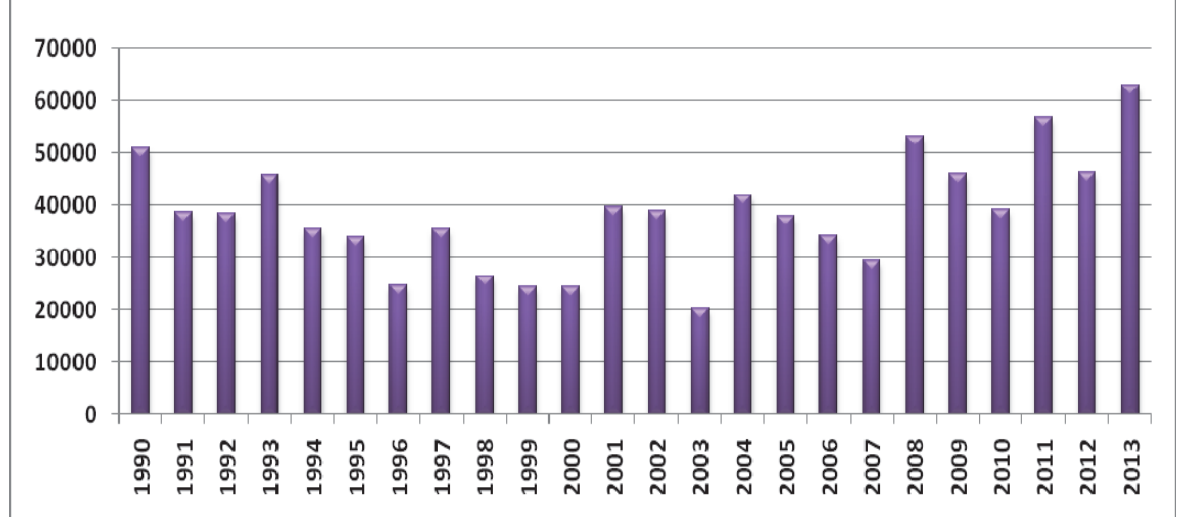

Figure 1 Dynamics of grain production in Ukraine in thousand tons Source: formed by the authors on the basis of (State Statistics Service of Ukraine)

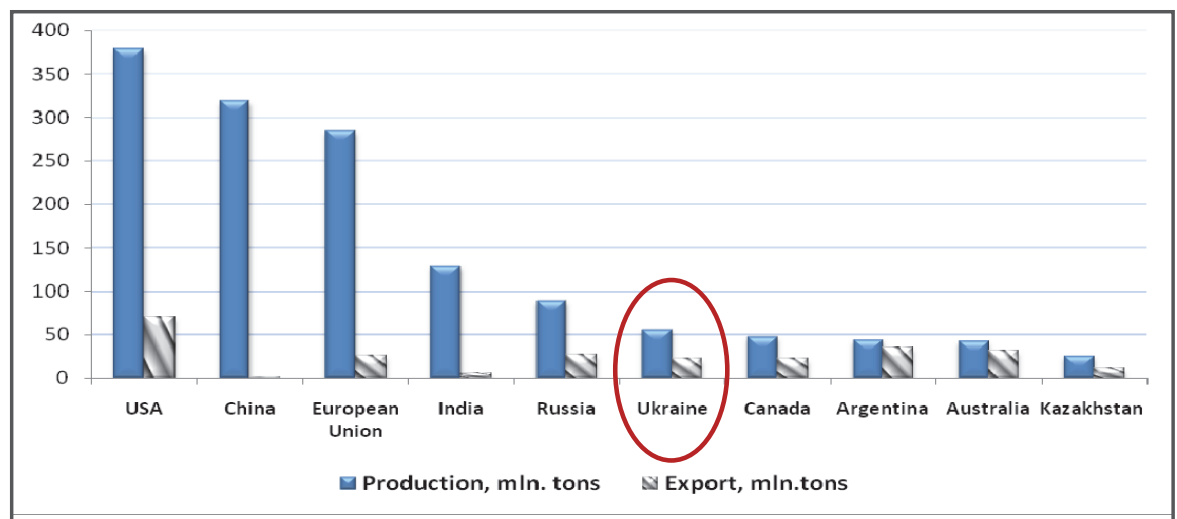

Figure 2 World production and export of grain, 2012

Source: formed by the authors on the basis of (Food and Agricultural Organization of the United Nations)

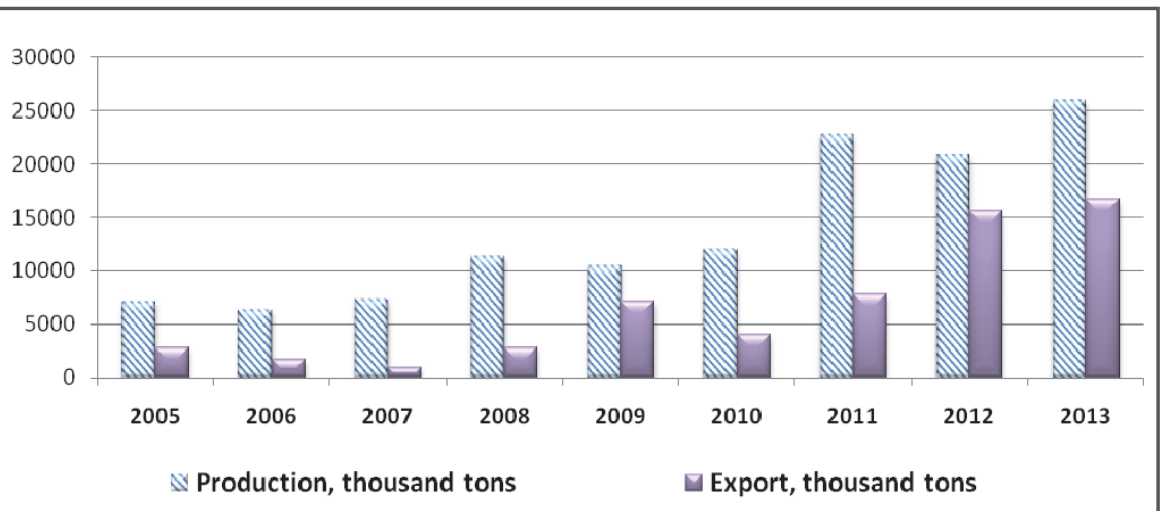

Figure 3 Corn export and production in Ukraine, 2005-2013

Source: formed by the authors on the basis of (State Statistics Service of Ukraine and Ministry of revenue and duties of Ukraine)

Thus 10-12 million hectares of agricultural lands are available for growing crops with subsequent processing into the biofuel.

We think that the most promising crops for bioethanol production in Ukraine are crops and the products of their first processing that contains the high amount of sugar and starch such as corn, feed grain, sugar and grain sorghum, sugar beets, intermediates of sugar beet processing, e.g. molasses, its volume is about 2 million ton predict their volume of production, so it varies every year (figure 1).

Analysis of the global market shows that among the biggest grain producers Ukraine occupies the leading positions among such big countries as the U.S, China, India and Russia (figure 2). However, the U.S. export 18.5\%, China $-0.3 \%$, EU $-9.3 \%$ India $-4.3 \%$ of their gross production of grain, Ukraine exports $41 \%$.

Considering Ukraine's dependence on energy import, unstable agriculture and high unemployment, especially in rural areas, it is not effective to sell abroad almost half of our gross yield of grain as a raw material.

Corn is an important grain crop for the production of bioethanol in Ukraine, it has a special place in the national and global grain production. It is the most distinguished among other crops considering the potential yield and diversity of use.Corn is widely used in food, starch, biofuel, microbiology, medical and other industries, and it has good feeding qualities (Kaletnik, 2010). In Ukraine food consumption of corn is minimal and most of the gross production is being exported (figure 3 ).

Figure 3 shows that there is a gradual increase in the production of corn in Ukraine. In particular, 2013 was a record year of the last decade as to this positive trend. The acreage was over 4.795 million hectares and the yield was $54.2 \mathrm{~kg} / \mathrm{ha}$; they formed the largest total corn yield of 26 million tons. Corn exports were 16.729 million tons in 2013. The ethanol yield is 40 litter from $100 \mathrm{~kg}$ of grain (Shiyan, Sosnitsky, Oliynichuk, 2009) (considering that at the temperature of $20^{\circ} \mathrm{C}$ the density of ethanol is $0.79 \mathrm{~g} / \mathrm{cm}^{3}$, we can get $0.316 \mathrm{t}$ of bioethanol from 1 ton of corn). If we processed corn that is now exported from Ukraine, we would have received 5.286 million tons of bioethanol.

However, the increased production of bioethanol causes the growth of demand for feed grain for its production. It reduces cropping areas of food grains, creates its shortfall and generally increases the cost of grain. Therefore, the most promising feedstock for bioethanol production is sugar beet and intermediates of sugar production. Sugar beet traditionally occupies the leading position among other industrial crops in Ukraine. The volume of sugar beet production decreased significantly because of the lost export opportunities in the early 1990s, now it is at the level that can only satisfy required internal demand for sugar in Ukraine (figure 4).

According to the indices of Ukrainian Scientific Research Institute of Alcohol and Foods Biotechnology the yield of bioethanol is 80-100 liters from 1 ton of sugar beets. Thus 


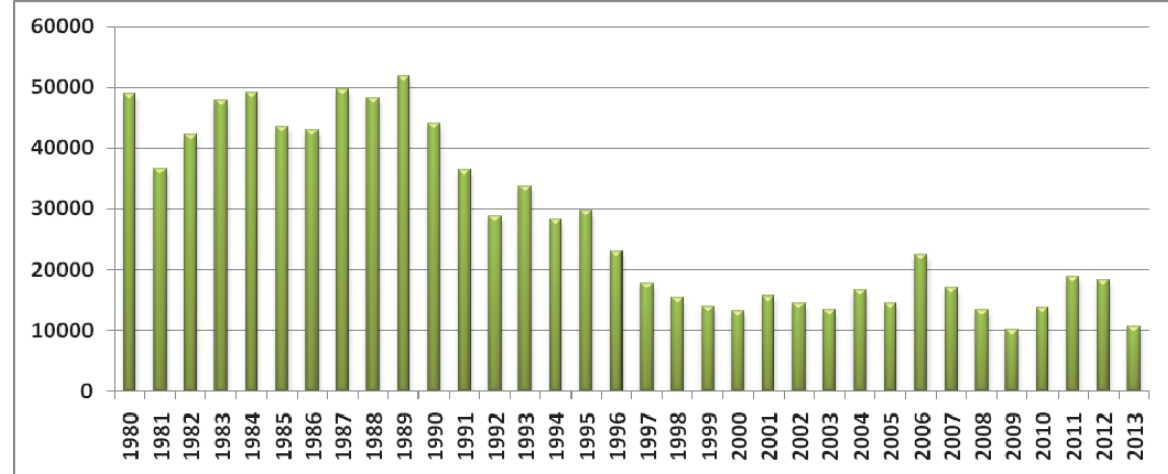

Figure 4 Dynamics of gross sugar beet harvest in Ukraine, thousand tons (1980-2013 years) Source: formed by the authors on the basis of (State Statistics Service of Ukraine)

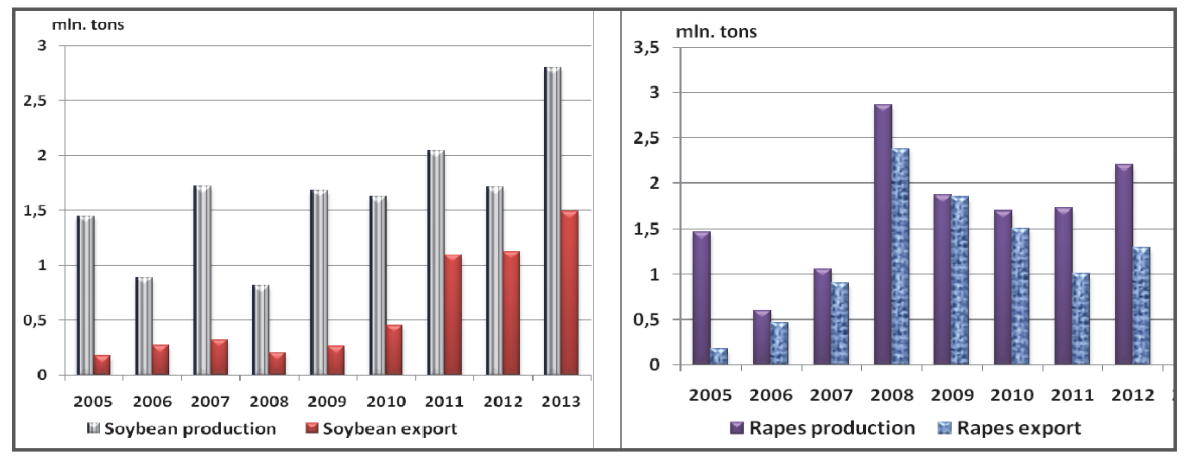

Figure 5 Production and export of rapeseed and soybean in Ukraine

Source: formed by the authors on the basis of (State Statistics Service of Ukraine and Ministry of revenue and duties of Ukraine)

the production of 1 ton of ethanol requires 12.6-15.7 tons of sugar beet (Shiyan, Sosnitsky and Oliynichuk, 2009). Considering that the density of ethanol at $20^{\circ} \mathrm{C}$ is $0.79 \mathrm{~g} / \mathrm{cm}^{3}$, the yield of bioethanol is $79 \mathrm{~kg}$ from 1 ton of sugar beet. Thus, if the cultivation of sugar beet in Ukraine is at the level of 1990 and processing part of the crop not involved in the production of sugar into bioethanol (which is about 25 million tons) Ukraine will produce approximately 1.975 million tons of bioethanol.

The production and consumption of biofuels from sugar beets can become a stabilizing factor for the sustainable development of sugar beet domestic production. Experience of leading countries shows that launched production and use of bioethanol from sugar beet and intermediates of sugar beet processing (molasses, sugar syrup, diffusion juice and second carbonation) plays an important role along with clear, understandable and flexible legislative levers of state regulation of economic relations in the sugar industry in these countries.

In Ukraine the production of bioethanol is possible at the sugar and alcohol plants. The concept of bioethanol production in Ukraine includes several areas:
1. Production of ethanol at the re-equipped ethanol production lines at existing sugar plants.

2. Reconstruction of existing alcohol plants and their conversion to bioethanol production facilities.

3. Construction of new plants for the production of biofuels considering cultivation area of raw materials.

The annual total capacity of distilleries in Ukraine is about 700 million liters of ethanol, including 340 million at the processing molasses plants (Kaletnik, 2008) Calculations show that the reconstruction of the existing distilleries will rise the production of ethanol fuel in Ukraine up to 0.3 million tons per year. Retrofitting refineries with specific production lines will make possible production of 1.65 million tons of ethanol per year. Thus, we could produce 2 million tons of bioethanol per year even without the construction of new plants, considering all areas of the biofuels market development in Ukraine.

For recent years the interconnection of domestic and world market of oilseeds and products of their processing is becoming more massive due to the international labor division developing and becoming of Ukraine among the oilseeds producing leaders such as producers of sunflower, rapeseed and soybean. The growth of demand for the crop oils usage at the biofuels industry led to a considerable increase of oilseeds gross yield in Ukraine. However, almost all grown in Ukraine rapeseed and soybean are being exported abroad (figure 5). Enterprises don't sell for export only that portion of total yield they will further need for seeding. Ukrainian rapeseed and soybean oils are not used for food industry, that oil is processed into biodiesel abroad.

To increase the state energy security agricultural sector of Ukraine should transform from an energy consumer to its producer. According to technological standards agriculture need about 1,870 tons of diesel fuel and 620 tons of gasoline every year (Ministry of Agrarian Policy and Food of Ukraine). 4.5 million tons of oil are needed to produce this amount of fuel, by the way it is mostly imported. Furthermore, the continuing growth of its value causes gasoline and diesel increasing costs and consequently agricultural products cost. Thus, the expenses of agricultural sector increased 6 times from 2000 to 2013. Therefore, the traditional way of satisfying the agricultural production needs by petroleum products is not perspective.

In 2012 soybean exports were 1.12 million tons and the export of rapeseed -1.29 million tons. Considering that the oil content of soybean and rapeseed is $17-25 \%$ and $48-52 \%$, Ukraine could produce about 900 tons of crop oil it would help to cover the agricultural needs in biodiesel by $100 \%$.

According to the Law of Ukraine "On alternative fuels" (The Verkhovna Rada of Ukraine) in 2014-2015 the mandatory content of biofuels as a part of conventional fuel should not be less than $5 \%$. As the average total annual fuel consumption in Ukraine is 5 million tons of gasoline and 6 million tons of diesel fuel (Ministry of Energy and (oal Industry of Ukraine), the production of biodiesel and bioethanol should not be less than 250 tons and 300 tons. Ukraine has the required resource potential to achieve these parameters. 1.25 million tons of soybeans and 500 tons of rapeseed should be processed to produce 250 tons of biodiesel ( $5 \%$ of the total consumption of diesel fuel) 1 million tons of corn (it exports were 16.729 million tons in 2013), or 3.8 million tons of sugar beets should be processed for the production of 300 thousand ton of bioethanol

The competitiveness of biofuels on the market may be improved by the cost reduction of energy crops used as raw materials for biofuels production. This can be achieved by increasing 
of crop yields per hectare to the level of major European countries using highly productive domestic and foreign varieties and implementation of the cultivation intensive technology.

To obtain maximum economic efficiency of biodiesel production it is necessary to create regional areas of concentrated cultivation of oilseeds with certain cultivated area to form the infrastructure for biodiesel plants.

Besides the crop yields other factors such as the cost of raw materials, content of sugar, starch or oil, processing and transportation costs and availability of byproducts affect the economic efficiency of biofuel production. In order to stimulate market development of liquid biofuels it is necessary to use economic regulation methods the effectiveness of which has been proven by other countries, namely, tax exemption on fuel, subsidy for refineries, credits for energy crops producers (payments to farmers, compensation in case of failure), the obligation to use biofuels, penalties for not obtaining established indicators.

\section{Conclusion}

All countries don't have strong agriculture. Ukraine has such competitive advantages in the production of alternative biofuels as fertile soils, favorable agricultural infrastructure and skilled workforce. A strong raw materials base for biofuels production has been formed in our country, considering favorable soil and climatic conditions, it includes the main starch, sugar and oil crops that give a high yield of biofuel per unit of production.

We must take into the consideration the national interests of Ukraine choosing between exports of raw materials and processing them into the final product. To overcome the energy dependence Ukraine should take the experience of leading countries and establish biofuel production from agricultural raw materials.

Complete solving of socio-economic, technological and environmental challenges of biofuel production is a prerequisite for the organization of large-scale production of bioethanol and biodiesel in Ukraine based on bioconversion of renewable plant raw materials.

One of the main conditions of the Ukrainian biofuel market functioning is a mandatory legal regulation of its usage in the production of mixed gasoline and diesel fuel; it will create supply and demand on biofuels at the domestic biofuels market and involve uninvolved facilities for its production.

Introduction of new innovative technologies in the field of energy supply will reduce dependence of Ukraine's economy on oil and gas exporting countries, will increase its energy, economic and national security and creates new quality level of relations with foreign countries that are exporters of oil. Biofuels production and consumption in Ukraine will help us to be considered as a state with the European level of energy, economic and environmental security.

\section{References}

BLUM, Y. - GELETUKHA, - G. GRYGORYUK, I. 2010. Biological resources and technologies for biofuels production. Kyiv : Agrar Media Group, 2010, 408 pp.

BLUM, Y. - GELETUKHA, - G. GRYGORYUK - DUBROVIN, V. 2010. New technologies bioconversion. Kyiv : Agrar Media Group, 2010, 326 pp.

BROWN, R. C. 2003. Biorenewable resources: engineering new products from agriculture. USA : lowa State press, 2003. $286 \mathrm{pp}$.

F00D and Agricultural Organization of the United Nations. Available at: http://www.fao. org/corp/statistics/en/

STATE Statistics Service of Ukraine. Available at: http://www.ukrstat.gov.ua/

KALETNIK, G. - OLIYNICHUK, S. - SKORUK, 0. 2012. Alternative Energy of Ukraine: features of functioning and prospects of development. Kyiv : Eldeveys and K, 2012. $250 \mathrm{pp}$.

KALETNIK, G. 2010. Biofuels. Food, energy and environmental security of Ukraine. Kyiv : Hi-Tech Press, 2010.516 pp.

KALETNIK, G. 2008. The development of the biofuels market in Ukraine. Kyiv : Agricultural Science, $2008.464 \mathrm{pp}$.

KALETNIK, G. 2008. Socio-economic importance of the biofuels market development in Ukraine. In: Economy of Agriculture, 2008, no. 6, pp. 128-132.

KOVALKO, M. - KOVALKO, 0. 2009. Developed Energy is the basis of National Security of Ukraine. Analysis of trends and opportunities. LLC "Publishing" Biznespoliraf, Kyiv, 2009, 104 pp.

MINISTRY of Agrarian Policy and Food of Ukraine. Available at: http://minagro.gov.ua/

MINISTRY of revenue and duties of Ukraine. Available at:: http://minrd.gov.ua/

MINISTRY of Energy and Coal Industry of Ukraine Available at: http://mpe.kmu.gov.ua/ fuel/control/uk/index.

ROYIK, M. - KURILO, V. - HANZHENKO, A. - HUMENTYK, M. 2012. Prospects for bioenergy development in Ukraine. In: Sugar beet, 2012, no. 2-3 (86-87), p. 6.

SHIYAN, P. - SOSNITSKY, V. - OLIYNICHUK, S. 2009. Innovative technologies of alcohol industry. Kyiv : Theory and Practice. Askania, 2009. 424 pp.

UKRAINETS, A. - HOMICHAK, L. - SHIYAN, P. - OLIYNICHUK, S. 2007. Ukrainian alcohol industry on the path to innovative development. In: Food and processing industry, 2007. pp. 16-19.

VERKHOVNA Rada of Ukraine. Available at: http://zakon4.rada.gov.ua/laws/show/139114.

\section{Contact address:}

Grygorii Kaletnik, Doctor of Economics, Professor, President of Vinnytsia National Agrarian University. Ukraine, Vinnytsia, Sonyachna Str, 3, 绝 0038 0432 460003, e-mail: rector@vsau.org. 